\title{
Konzervatív evolúció a zöld kémiában
}

\author{
MIKA László Tamás ${ }^{\mathrm{a}}$ és NÁRAY-SZABÓ Gábor, ${ }^{\mathrm{b}, *}$ \\ ${ }^{a}$ Kémiai és Környezeti Folyamatmérnöki Tanszék, Budapesti Müszaki és Gazdaságtudományi Egyetem, \\ 1111 Budapest, Müegyetem rkp. 3, Magyarország \\ ${ }^{b}$ Kémiai Intézet, Eötvös Loránd Tudományegyetem, 1117 Budapest, Pázmány Péter stny. 1A, Magyarország
}

\section{Bevezetés}

A vegyi anyagok azonosítására szolgáló CAS regisztrációs szám ma már nagyobb, mint 133 millió. A regisztrált vegyületek döntő többsége száz éve még nem létezett közülük igen sok környezet- és/vagy egészségkárosító hatású. A vegyipar óriási mennyiségben állít elő az emberre és a környezetre veszélyes anyagokat, azonban a legnagyobb elővigyázatosság mellett is nehéz elkerülni, hogy ezek káros hatást fejtsenek ki a környezetre. Nem véletlen tehát, hogy a kémia megítélése az utca embere szemében igen negatív és az elvitathatatlan előnyöket az őt közvetlenül érintő károk láttán nem értékeli. A zöld kémia a kedvezőtlen hatások minél teljesebb kiküszöbölésének szándékával több mint egy évtizede alakult ki és célja a veszélyes anyagok keletkezésének, használatának és mennyiségének minimalizálása az új vegyipari termékek és a kémiai folyamatok tervezése során. Anastas és Warner húsz éve fektette le a zöld kémia alapelveit, ${ }^{1}$ melyek segítik a vegyészt és a vegyészmérnököt, hogy környezettudatos tervezés és kivitelezés révén csökkentse a vegyipari termeléshez köthetö mellékhatásokat.

A zöld kémia irányelvei tulajdonképpen konzervatív fordulatot jelentenek, felismerve, hogy „Semmi sem új a nap alatt" (Prédikátor 1,9). Kifejezik a konzervatív evolúció elvét, ${ }^{2}$ mely szerint az univerzum fejlődése során csak azok a megoldások és szerkezetek voltak képesek fennmaradni, melyek szervesen ráépültek a bevált régiekre. Az elektron, a proton és a neutron közvetlenül az ősrobbanás után, mintegy 14 milliárd évvel ezelőtt alakult ki, de azóta is változatlan tulajdonságokkal maradt fenn az atomokban. $\mathrm{Az}$ aminosavak és a nukleotidok az élet molekuláinak (a fehérjéknek és a nukleinsavaknak) mással nem helyettesíthető alkotórészei, szerkezetük több milliárd éve változatlan. Hasonlóképpen stabil képződmény a sejt, az élölények elemi építőköve, a gerincoszlop, a gerincesek csontvázának nélkülözhetetlen eleme, és a kerék, ami számtalan erőátviteli és szárazföldi mozgató szerkezet alapvetö része.

Az anyagi termelö folyamatok környezeti hatásai a lehető legkisebbre csökkenthetők, ha utánozzuk az élő szervezetek körkörös kémiai folyamatait. Ezt az elvet követi az ipari metabolizmus, vagyis a hasonló fizikai folyamatok integrált rendszere. Ez a nyersanyagokat és az energiát emberi beavatkozással termékké és minimális mennyiségü hulladékká alakítja. ${ }^{3}$ Legújabb változata a körforgásos gazdaság, mely az anyagi termelő ágazatokat a tartós termékek előállítása, a megújuló rendszerek működtetése és a megújuló energia felhasználása felé tereli. Minimálisra csökkenti a mérgező anyagok mennyiségét, a hulladék lehető legnagyobb részét élő szervezetek számára hasznosítható tápanyaggá alakítja. Fontos vonása, hogy az ipari termékeket egész életciklusukra tervezi, így eleve figyelembe veszi a keletkező hulladékokat és legalább részben biztosítja azok újrahasznostását. ${ }^{4} \mathrm{Az}$ a cél, hogy csak ártalmatlan új vegyületek kerüljenek ki a természetes körforgásba.

Az alábbiakban párhuzamba állítjuk a zöld kémia Anastas és Warner által lefektetett néhány szabályát a konzervatív evolúció alapelveivel és kimutatjuk, hogy ezek megfeleltethetök egymásnak. A téma részletes kifejtését egy nagyobb lélegzetü közleményünkben végeztük el. ${ }^{5}$ Ezzel a cikkel is tisztelgünk Horváth István Tamás, a katalitikus - és a zöld kémia világhírü szaktekintélyének munkássága előtt, hatvanötödik születésnapja alkalmából.

\section{Atomhatékonyság}

Az ipari metabolizmus kiváló példáját mutatja a zöld kémia második alapelve, ${ }^{1}$ mely szerint úgy kell tervezni a szintéziseket, hogy a kiindulási anyagok lehető legnagyobb mértékben beépüljenek a végtermékekbe. ${ }^{6} \mathrm{Az}$ atomhatékonyság jó mérőszáma a kívánt termék és az alkalmazott összes reagens tömegaránya. Ez 100\% addíció és izomerizáció, mintegy $80 \%$ a legtöbb katalitikus reakció esetében, $50 \%$ a rezolválásnál, és csak $20 \%$ körül van szubsztitúciós reakciók esetében. Azt is figyelembe kell venni, hogy kémiai folyamatokban gyakran használnak különböző segédanyagokat annak érdekében, hogy elérjék a teljes atomhatékonyságot. Nyilvánvaló, hogy ezek sorsát követni kell a végtermék elkülönítése után is. A teljes folyamat környezeti hatásának becslésére széles körben használják a Sheldon-féle E-faktort, vagyis a hulladék és a kívánt termék tömegarányát. ${ }^{7} \mathrm{Az}$ atomhatékonysággal együtt alkalmazva pontosabb képet kaphatunk egy kémiai folyamat környezetre gyakorolt hatásáról.

Nyilvánvaló, hogy a teljes atomhatékonyság jó példáit szolgáltatják az addíciós reakciók. Horváth és munkatársai már majdnem negyven évvel ezelőtt leírták a szén-monoxid és az acetilén konverzióját bifurándionokká (1. ábra). ${ }^{8}$ Ezek a vegyületek a múanyagipar fontos kiinduló anyagai. A kobalt-oktakarbonillal katalizált reakció atomhatékonysága 
$100 \%$, azonban a kitermelés igen alacsony, csak 4-6\%. Kimutatták, hogy tercier trialkilfoszfinok és trialkilfoszfitok alkalmazásával, a foszforatomon lévő ligandumtól függően ez akár hetven százalékra növelhető. Acetilén és szén-monoxid reakciója esetében, $\mathrm{P}(\mathrm{nBu})_{3}$ jelenlétében a kitermelés eléri a $72 \%$-ot.

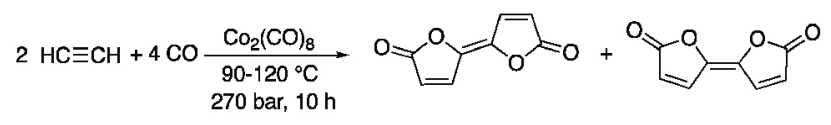

1. Ábra. Szén-monoxid és az acetilén konverziója bifurándionokká.

Jó az atomhatékonysága a szelektív hidrogénezési reakcióknak is. Egy ipari szempontból fontos példa erre a furfural konverziója furfurilalkohollá. ${ }^{9}$ Ez folyadék vagy gázfázisban zajlik az erősen mérgező rézkromit katalizátor jelenlétében. Számos kísérletet tettek egy másik, nem mérgező katalizátor kifejlesztésére, hogy csökkentsék a környezeti kockázatokat. Nemrégen kimutatták, hogy a $\mathrm{Ru} / \mathrm{Ph}_{2} \mathrm{P}\left(\mathrm{CH}_{2}\right)_{4} \mathrm{PPh}_{2}$ rendszer oldószer vagy segédanyag távollétében is az átalakítás aktív katalizátora, ezáltal egy környezeti szempontból barátságos reakcióút nyitható meg (2. ábra). A katalizátor akár tizenkétszer is újrahasznosítható anélkül, hogy aktivitása csökkenne. ${ }^{10}$

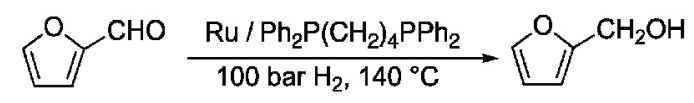

2. Ábra. Furfural szelektív konverziója furfurilalkohollá.

A müanyagipart sokan vádolják a környezet túlzott terhelésével. Termelése hatalmas, 2014-ben 300 millió tonnára rúgott, ezért különösen fontos, hogy a polimerizációs reakciók esetében megvalósul a száz százalékos atomhatékonyság. Jó példa az etilén vagy más olefin átmeneti fémmel katalizált polimerizációja, melynek kiemelt szerepe van a polimer-kémiában.

\section{Biztonságos segédanyagok}

A zöld kémia negyedik alapelve szerint a vegyipari termékeket úgy kell tervezni, hogy a lehető legjobban megmaradjon kívánt funkciójuk, ugyanakkor a lehető legkisebbre csökkenjen a környezetkárosító hatás. ${ }^{1} \mathrm{Ez}$ többek között úgy érhető el, hogy biztonságos segéd-anyagokat használunk. Ilyen például a környezetbarát ă-valerolakton (GVL), melyből a 3. ábra szerint számos átmeneti termék állítható elő a vegyipar számára. ${ }^{11}$ Előnyös vonása, hogy biomasszából is származtatható. ${ }^{12}$ Ez a vegyület számos gyümölcs alkotórésze, gyakran használják élelmiszerekhez adalékanyagként. Széles hőmérséklettartományban folyadékállapotú, csekély a toxicitása, korlátlan mértékben elegyíthetô vízzel, kicsi a gőznyomása és számos további előnyös tulajdonsága van. Vízzel és alkoholokkal nem alkot azeotrópos elegyet, ezért könnyen elválasztható tőlük. Elöállítására több oldószermentes eljárást fejlesztettek ki. ${ }^{13}$

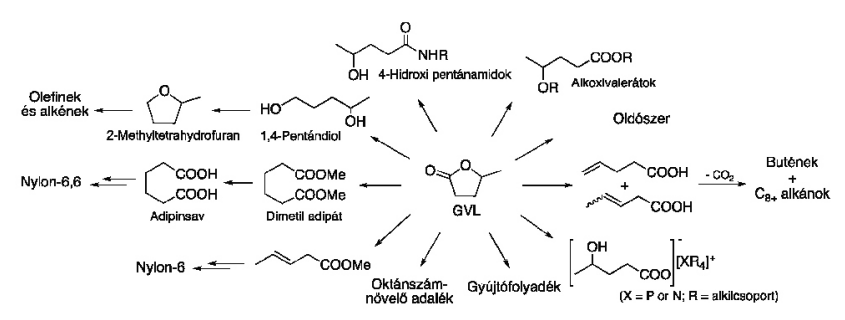

3. Ábra. $\gamma$-valerolaktonból előállítható vegyipari termékek.

Másik biztonságos segédanyag a dimetilkarbonát, mely fontos szerepet játszik a vegyiparban. Kicsi a toxicitása, ezért nem veszélyes sem az emberre, sem más élőlényekre és nincs korróziós hatása. Megfelelő katalizátor alkalmazásával számos karbonilező, karboximetilező, metilező szer és más vegyipari intermedier, például foszgén, metoxi-karbonilklorid, demetilszulfát és különböző metilhalogenidek építhetők fel belőle. ${ }^{14}$

\section{Biztonságos oldószerek}

Az oldószerek számos kémiai reakció elválaszthatatlan részei, ezért érthető, hogy kifejlődött az „oldószeres kémiai gondolkodás", mely számos előnyt kínál a laboratóriumi és ipari müveletek esetében egyaránt. Alkalmazásuk fontos többek között a hőmérséklet szabályozásában, a szilárd anyagok oldatba vitelében a reakció közös fázisának létrehozásában és a keverés megkönnyítésében. A reakciók nagy többsége csak folyadékfázisban játszódik le, így alkalmazásuk óriási mérteket ölt, amelynek eredménye-képpen az ipari tevékenység sok illékony oldószert juttat a levegőbe. Az Európai Unió huszonnyolc tagállama hatmillió tonnát bocsát ki évente, ezek közül néhány komoly környezeti veszélyeket rejt magában. Ezért fogalmazták meg a zöld kémia ötödik alapelvét, mely szerint az oldószerek és más segédanyagok használatát - ha lehet mellőzni kell. ${ }^{1}$ Ha mégsem, lehetőleg ártalmatlan anyagokat kell használni oldószerként. Ezért fontos a hagyományos szerves oldószerek kiiktatása vagy helyettesítése környezetkímélő anyagokkal (melyek gőznyomása kicsi, toxicitásuk elhanyagolható és nem gyúlékonyak) nélkülözhetetlen része a tisztább vegyipari technológiák kifejlesztésének.

Nyilvánvaló, hogy az oldószermentes reakciófeltételek csak az oldószer, mint segédanyag teljes eliminációjával érhetők el. Ha az egyik reagens a reakció körülményei között folyékony, mintegy „belső oldószer”-ként müködhet. Ezekben az esetekben nem pontos az „oldószermentes” kifejezés, helyette a „külső oldószertől mentes” jelzőt javasolt használni. A közeg összetétele a reakció során folytonosan változik. Jó példa erre a levulinsav hidrogénezése 4-hidroxivaleriánsavvá egy olyan katalizátor jelenlétében, mely in situ, a $\mathrm{Ru}(\mathrm{acac})_{3}$ és $\mathrm{P}(\mathrm{nBu})_{3}$ vagy $\mathrm{Ph}_{2} \mathrm{P}\left(\mathrm{CH}_{2}\right)_{4} \mathrm{PPh}_{2}$ ligandumokból keletkezik. ${ }^{15}$ 
Az ionos folyadékok is rengeteg kémiai átalakítás esetében alkalmazhatók alternatív reakcióközeg gyanánt. Igen kicsi a gőznyomásuk, jó oldószerek, megfelelő a termikus stabilitásuk, kémiai és fizikai tulajdonságaik könnyen szabályozhatók. ${ }^{16,17}$ Bár laboratóriumi körülmények között igen gyakran, ipari méretben csak ritkábban alkalmazzák ezeket. Horváth és munkatársai jöttek rá arra, hogy ionos folyadék keletkezik a ciklohexanon oxim $\varepsilon$-kaprolaktámmá való átrendeződési reakciója során, kénsav jelenlétében (4. ábra). ${ }^{18} \mathrm{Az}$ átrendeződés kén-trioxid jelenlétében történik a termék és a kénsav alkotta ionos folyadékban. Ilyen módon ipari körülmények között valósul meg egy külső oldószertől mentes kémiai transzformáció. Az ionos folyadékok kémiájában elért eredményekről, jellemzésükről, előállításukról és alkalmazásaikról részletesen olvashatunk egy nemrégiben megjelent összefoglalóban. ${ }^{16}$

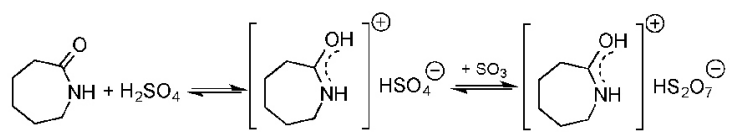

4. Ábra. \&-kaprolaktámium típusú ionos folyadékok keletkezése.

A glicerin könnyen elérhető, biológiailag könnyen lebontható, környezetkímélő oldószer, mely ipari méretekben keletkezik a természetes zsírsavak trigliceridekkel való átészterezése során. Toxicitása jóval kisebb, mint a metanolé vagy az etanolé. Miután egyre nő az igény a biodízel motorhajtóanyagok iránt, egyre nagyobb mennyiségben termelik. Mindazonáltal, oldószer minőségű glicerint jelentős energiaigényű tisztítási folyamat során lehet csak előállítani. Jérôme és munkatársai kimutatták, hogy a $p$-anizidin és a butirakrilát között végbemenő modellreakció $\quad 100 \quad{ }^{\circ} \mathrm{C}$ hőmérsékleten végrehajtható. ${ }^{19}$ Míg glicerinben a kitermelés $80 \%$-os volt, hagyományos szerves oldószerekben, például toluolban, dimetilszulfoxidban vagy dimetilformamidban csak 5\%-nál kisebb konverziót figyeltek meg.

A fluoros oldószerek (perfluorozott alkánok, dialkiléterek, trialkilaminok) extrém apoláris környezetet biztosítanak a reakciók számára. Szobahőmérsékleten alig keverednek közönséges szerves oldószerekkel (toluol, aceton, tetrahidrofurán, alkoholok). Következésképpen ezek a folyadékok könnyen képeznek kétfázisos rendszereket. A fluoros oldószer koncepciót először Horváth és Rábai vezették be, mint a vizes oldószer analógját, ezáltal kiemelve azt, hogy a kettőből az egyik fázis fluorozott szénhidrogénekben gazdagabb, mint a másik. ${ }^{20}$ A kétfázisú fluoros rendszerek számos kémiai reakció esetében hasznosíthatók a katalizátor immobilizálására. Egy ilyen tipikus rendszer egy fluoros fázist tartalmaz valamely, ebben oldható katalizátorral, és egy másik, termékfázist, mely bármely, a fluoros fázisban csupán kismértékben oldódó szerves vagy szervetlen oldószer lehet. A legalkalmasabb fluoros molekularészletek lineáris vagy elágazó, nagy szénatomszámú perfluoroalkil láncok, melyek tartalmazhatnak heteroatomot. A módszer nagy teljesítőképességét olefinek hidroformilezésénél mutatták ki először. A fluoros fázisban oldódó katalizátor-rendszer $\left(\mathrm{Rh} / \mathrm{P}\left[\mathrm{CH}_{2} \mathrm{CH}_{2}\left(\mathrm{CF}_{2}\right)_{5} \mathrm{CF}_{3}\right]_{3}\right)$ kiválóan alkalmazható decén-1 hidroformilezésére $100{ }^{\circ} \mathrm{C}$ hőmérsékleten, 11 bar szintézisgáz nyomáson. A keletkező aldehideket könnyen el lehet választani a fluoros katalizátortól. Kilenc reakció/elválasztás ciklus után a katalitikus ciklusszám több mint 35000 volt, és mindössze 1,18 pm volt az undekanál egy móljára számított katalizátorveszteség. A kétfázisú fluoros rendszer sémáját az 5 . ábrán láthatjuk.

Kiváló, környezetkímélő oldószerek a szerves karbonátok is melyek lehetnek aciklusosak (dimetil- vagy dietil-karbonát) és ciklusosak (propilén-karbonát), ezek számos kiváló fizikai és kémiai tulajdonsággal rendelkeznek. Kicsi a gőznyomásuk és a toxicitásuk, szagtalanok és biológiailag könnyen lebonthatók. Újabban fontos szerepet játszanak a kozmetikai iparban és gyakran használják öket, mint biztonságos oldószereket élelmiszerek és takarmányok előállításánál.

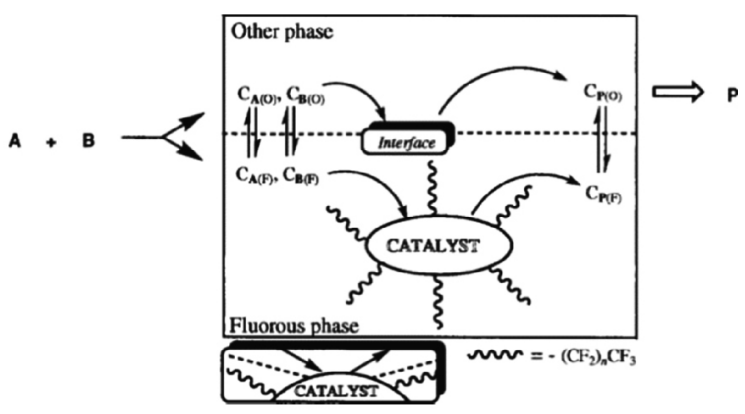

5. Ábra. Az A és a B szubsztrátok katalitikus konverziója P termékké kétfázisú fluoros rendszerben. The American Association for the Advancement of Science (1994) engedélyével.

A szuperkritikus szén-dioxid gyakran használatos alternatív reakcióközeg. Olcsó és könnyen beszerezhető oldószer akár egymagában, akár másokkal (szénhidrogének, ionos folyadékok, fluoros oldószerek) kombinálva. A gáz fizikai tulajdonságainak következtében nem kell figyelembe venni a termék szennyeződését akkor, ha véletlenül kijut a környezetbe, de akkor sem, ha a szennyezés a termék végső elválasztásakor következik be. Ez teszi lehetővé a szuperkritikus szén-dioxid alkalmazását az élelmiszer és tápszeriparban vagy koffein kivonására a kávészemekből. Gyógyszeripari példa a racém ibuprofén elválasztása, mely $(R)$-(1)-feniletil-amin-nal való diasztereomer sóképződésen alapul. Ezt követi a gáz antioldószer módszerrel történő kicsapása, aminek során az (S)-ibuprofen 80\%-os kitermelése is elérhető. ${ }^{22}$

\section{Megújuló alapanyagok}

Jelenleg az emberiség energiaszükséglete, valamint a szén-alapú vegyszerek kb. 90\%-a fosszilis forrásokból származnak. Nehéz megjósolni a nyersolaj, mint a vegyipar fő karbonforrása kimerülésének pontos időpontját, erről folyamatosan élénk vita folyik. 2014-ben a tartalékokat 1700 milliárd hordóra becsülték, ez mintegy 600 milliárddal több, mint a húsz évvel ezelőtti becslés. A tartalék több mint fele jelenleg a Közel-Keleten található. ${ }^{23}$ Ennek ellenére, a szén-dioxid kibocsátás megfékezése érdekében kifejtett globális erőfeszítések arra késztették a kutatókat, hogy fordítsanak nagyobb figyelmet a szén-alapú nyersanyagok megújulókkal való helyettesítését célzó, innovatív eljárásokra. A vízi energia, a szél és a fotovoltaikus energia harminc éve jön szóba, mint reális alternatíva, a vegyipar 
számára pedig a biomassza, mint a mindenütt könnyen fellelhető alapanyag jelentheti a megoldást. Nyilvánvaló ennek összefüggése a konzervatív evolúcióval: a kémiában felhalmozódó, hatalmas mennyiségü ismeret birtokában visszatérünk a természetes megoldásokhoz, melyek szervesen ráépülnek a régiekre. A zöld kémia hetedik alapelve ezt veszi figyelembe: ha csak lehet, megújuló alapanyagokból kell kiindulni a vegyipari folyamatok tervezése során. ${ }^{1}$

Figyelembe véve a Föld növekvő népességét, a megfelelő nyersanyagforrások kiválasztása és kitermelése súlyos ellentmondásokhoz vezetett. Emiatt elmondhatjuk, hogy energia termelése és szénalapú vegyipari termékek előállítása biomasszából nem versenyképes. Másrészt, a biomassza iránti megnövekedett igény növeli a földhasználatot, melynek ma már szigorú korlátai vannak. Nyilvánvaló, hogy a megfelelő megoldás az lenne, ha lignocellulózban gazdag hulladékot használnánk fel, mert nincs lényeges különbség a primer biomassza alapú nyersanyagforrások és például az erdészetből vagy az élelmiszeriparból származó hulladék között. Ennek megfelelően igen intenzív kutatási tevékenység irányul a biomassza felhasználására hasznos vegyipari alapanyagok (üzemenyagok, szén alapú intermedierek) előállítása céljából. Ezek az úgynevezett ,platform vegyületek” részben vagy egészben helyettesíthetik a jelenleg használt fosszilis alapú anyagokat. A lehetséges helyettesítőket szénhidrátokból lehet előállítani. ${ }^{24}$

Bár a biomassza ideális alternatíva lenne, fenntartható hasznosítása attól függ, hogy lesz-e elég belőle ahhoz, hogy fedezze az egyre növekvő igényeket a nyersanyagok és vegyipari termékek iránt. A biomassza hasznosításának célszerü fejlesztését a fenntarthatóság Horváth és munkatársai által adott, új definíciója könnyíti meg. ${ }^{25}$ Eszerint (1) az erőforrások (az energiát is beleértve) csak olyan ütemben használhatók fel, amilyen ütemben azok természetes úton pótolhatók; (2) a hulladékok termelődése nem lehet gyorsabb, mint ártalmatlanításuké. Ez az új megközelítés kifejezi az időbeli változást, a kinetikát és lehetőséget nyújt arra, hogy meghatározzuk a fenntarthatóság értékét egy adott vegyületre. Az üzemanyagok és a vegyipari alapanyagok fenntarthatóságának kvantitatív jellemzésére egy új mérőszámot vezettek be, ez az etanolekvivalens. A mérőszámot további szempontok figyelembe vételével továbbfejlesztették. ${ }^{26}$

A biomassza komplex hasznosítására irányuló első közelítést leginkább a „biofinomító elv” néven nevezhetjük, mely oly módon integrálja az átalakítási folyamatokat az üzemanyagok, energia, hő és hasznosítható vegyületek előállítása céljából, hogy a kiindulási anyag valamennyi szénatomját hasznosítsa, vagyis a lehető legnagyobbra növelje az atomhatékonyságot. Sajnos, a lignocellulóz összetettsége miatt ezt csak részben lehet megvalósítani.

\section{Katalízis}

A zöld kémia kilencedik ajánlása szerint az átalakítások során a folyamatosan fogyó, sztöchiometriai reagensek helyett lehetöleg katalitikus reagenseket kell használni, melyek mennyisége a reakció során lényegében nem csökken. ${ }^{1}$ Egy reakció szelektív felgyorsítása lehetővé teszi a melléktermékek mennyiségének csökkentését, a kémiai katalízis tehát tükrözi az ipari metabolizmus elveit. Az átmeneti fémek részvételével zajló homogén katalízis révén igen sok kémiai átalakítás végezhető el. Az ilyen folyamatok környezeti szempontból előnyösebbek, mint heterogén fázisban végbemenő megfelelőik. Jól szabályozhatók, ezért szignifikánsan nagyobb a kemoszelektivitásuk, régiószelektivitásuk és enantio-szelektivitásuk, enyhébb reakciókörülmények között játszódnak le. Mindazonáltal, nagy kihívást jelent a katalizátor elválasztása vagy újrafelhasználása, ami az utóbbi időkben jelentős kutatási aktivitást váltott ki. Számos vonzó megoldást fejlesztettek ki, ilyen például a bifázisos katalízis ${ }^{27}$ vagy a homogén katalizátorok heterogenizálása. ${ }^{28}$

A biokatalízis kiváló lehetőséget kínál egy vagy több királis centrummal rendelkező, biológiailag aktív vegyületek előállítására. Ezt ismerte fel néhány gyógyszergyár, mely integrálta ezt a zöld és fenntartható módszert a hagyományos gyógyszerkémiával. Nem kétséges, hogy a modern gyógyszeripar nem müködhet biotechnológia nélkül. Miután nagyszámú enzimet, vagyis biológiai katalizátort ismerünk már hosszú ideje, a fehérje- és génmódosítási technikák révén optimizálható vagy javítható az ismert biokatalizátorok hatékonysága. Lehetőség nyílik arra, hogy újtípusú biokatalitikus átalakításokban használjuk ezeket, melyek eddig a természetben ismeretlenek voltak. A biokatalitikus átalakításokról számos összefoglaló jelent meg, ezek közül csak a legújabbat idézzük. ${ }^{29}$

A gyógyszeriparban a biokatalizátor alkalmazása lehetővé teszi a szintézislépések számának csökkentését, nagyobb tisztaság elérését, a kitermelés növelését. Erre egy példa a Pfizer által kifejlesztett eljárás a központi idegrendszerre ható, antiepileptikus gyógyszer, a Pregabalin [(S)-3(aminometil)-5-metilhexánsav] szintézisére. Az eredeti, kereskedelmi célú szintézis egy Knoevenagel kondenzációval indul, melyet racém elegyhez vezető cianid reakció, hidrolízis, dekarboxilezés és hidrogénezés követ. Klasszikus királis rezolválási technika alkalmazásával, (S)-(+)-mandulasavval képeztek diasztereomer sót, amit azután izopropilalkohol/víz elegyben kristályosítottak át. A tiszta terméket tetrahidrofurán/víz elegyből, többszöri átkristályosítással izolálták. ${ }^{30} \mathrm{Az}$ új megoldás a $\beta$-cianodiészter egyik észtercsoportjának enzimkatalizált hidrolízise, ami jelentősen csökkenti a melléktermékek mennyiségét és növeli a végtermék kitermelését (6. ábra). ${ }^{31}$ A reakció során felhasznált oldószer mennyisége alig több mint a tizedére csökkent.

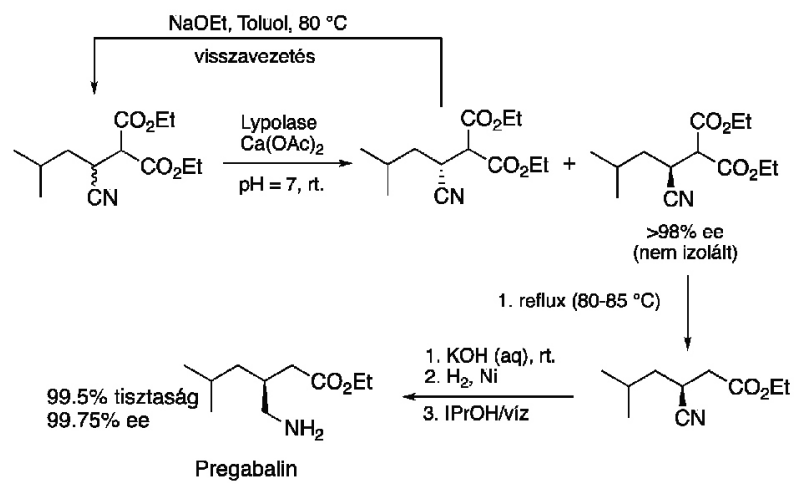

6. Ábra. A Pregabalin enzimatikus szintézise. 


\section{In situ analízis}

Az in situ analízis, vagyis a reakciótermékek analízise a keletkezésük helyén egyike az élet alapvető folyamatainak. Például az élő sejtek DNS molekuláit folyamatosan támadják és károsítják külső behatások, mint az UV sugárzás, a rákkeltő anyagok, a szabad gyökök. A sejtosztódás, a DNS replikáció során a sejt felismeri és helyrehozza a bekövetkezett hibákat. A téma fotosságát nem lehet túlbecsülni, mert javító mechanizmusok nélkül nem lehetne élet. Nem csoda, hogy ezért a felfedezésért ítélték oda a 2015. évi kémiai Nobel díjat. ${ }^{32}$

A biológiai evolúció során, évmilliók alatt pontos in situ analitikai folyamatok fejlődtek ki, melyek lehetővé teszik, hogy a szervezet nyomon kövesse a biokémiai átalakulásokat. Az ember által folytatott kutatások során azonban a kémiai átalakulások mechanizmusának jobb megértése, a melléktermékek mennyiségét csökkentő,

\section{Hivatkozások}

1. Anastas, P., Warner, J.C. Green Chemistry: Theory and Practice, Oxford University Press, New York, 1998.

2. Náray-Szabó, G. CLCWeb: Comparative Literature and Culture 2014, 16.1, (letöltve 2018. április 3-án) https://doi.org/10.7771/1481-4374.2316

3. Ayres, R.U. Industrial metabolism: Theory and policy. In: Ayres, R.U., Simonis, U.K. (Eds.), Industrial Metabolism: Restructuring for Sustainable Development. United Nations University Press, Tokyo, 1994.

4. Pearce, D.W., Turner, R.K. Economics of Natural Resources and the Environment. Johns Hopkins University Press, Baltimore, 1989.

5. Mika, L., Náray-Szabó, G. Green Chemistry, 2018, in press https://doi.org/10.1039/C8GC00514A

6. Trost, B.M. Science, 1991, 254, 1471-1477., https://doi.org/10.1126/science.1962206

7. Sheldon, R. A. Chem. Ind. (London), 1992, 903-906.

8. Váradi, G., Horváth, I.T., Palágyi, J., Bak T., Pályi, G. J. Mol. Catal., 1980, 9, 457-460. https://doi.org/10.1016/0304-5102(80)80038-1

9. Mika, L.T., Cséfalvay E., Németh, Á. Chem. Rev., 2018, 118, 505-613., https://doi.org/10.1021/acs.chemrev.7b00395

10. Tukacs, J.M., Bohus, M., Dibó G., Mika, L.T. RSC Adv., 2017, 7, 3331-3335., https://doi.org/10.1039/C6RA24723G

11. Horváth, I.T., Mehdi, H., Fábos, V., Boda, L., Mika, L.T. Green Chem., 2008, 10, 238-242., https://doi.org/10.1039/B712863K

12. Mehdi, H., Fábos, V., Tuba, R., Bodor, A., Mika, L.T., Horváth, I.T. Top Catal, 2008, 48, 49-54., https://doi.org/10.1007/s11244-008-9047-6

13. Geilen, F.M.A., Engendahl, B., Harwardt, A., Marquardt, W., Klankermayer, J., Leitner, W. Angew. Chem. Int. Ed., 2010, 49, 5510-5514., https://doi.org/10.1002/anie.201002060

14. L. pl. Selva, M., Perosa, A. Green Chem., 2008, 10, 457-464.

15. Tukacs, J.M., Novák, M., Dibó, G., Mika, L.T. Catal. Sci. Technol 2014, 4, 2908-2912., https://doi.org/10.1039/C4CY00719K

16. Z. Lei, B. Chen, Y.-M. Koo and D. R. MacFarlane, Chem. Rev., 2017, 117, 6633-6635., https://doi.org/10.1021/acs.chemrev.7b00246 szelektív katalizátorok tervezése nagy kihívást jelent. Nem meglepő tehát, hogy a zöld kémia tizenegyedik alapelve azt mondja ki, hogy analitikai módszereket kell kifejleszteni, melyek lehetővé teszik, hogy a reakciót folyamatosan monitorozzák, ezzel lehetővé téve a veszélyes anyagok folyamatos, valós idejü megfigyelését és ellenőrzését. ${ }^{1}$ Az in situ spektroszkópia kulcsszerepet játszik a reakciómechanizmusok felderítésében, valós időben képes jellemezni a reakciók mechanizmusát. Adott, a gyenge reakciókészséghez vezető speciesz jelenlétének igazolása vagy új intermedierek felfedezése jól ismert reakciók eltérő mechanizmusának felfedezéséhez is vezethet. Például, hosszú ideig feltételezték, hogy a formil kation $[\mathrm{HCO}]^{+}$ kulcsszerepet játszik a szén-monoxid savas közegben lejátszódó reakciói esetében. Jelenlétét először húsz éve mutatták ki infravörös és mágneses magrezonanciaspektroszkópia segítségével.

17. J. P. Hallett and T. Welton, Chem. Rev., 2011, 111, 3508-3576., https://doi.org/10.1021/cr1003248

18. V. Fábos, D. Lantos, A. Bodor, A.-M. Bálint, L. T. Mika, O. E. Sielcken, A. Cuiper and I. T. Horváth, ChemSusChem, 2008, 1, 189-192., https://doi.org/10.1002/cssc.200700135

19. Y. Gu, J. Barrault, F. Jérôme, Adv. Synth. Catal., 2008, 350, 2007-2012., https://doi.org/10.1002/adsc.200800328

20. Horváth, I. T., Rábai, J., Science, 1994, 266, 72-75., https://doi.org/10.1126/science.266.5182.72

21. Zosel, K. Angew. Chem. Int. Ed. Engl. 1978, 17, 702-709., https://doi.org/10.1002/anie.197807021

22. Lőrincz, L., Bánsághi, G., Zsemberi, M., de Simón Brezmes, S., Szilágyi, I.N., Madarász, J., Sohajda T., Székely, E., J. Supercritical Fluids, 2016, 118, 48-53., https://doi.org/10.1016/j.supflu.2016.07.021

23. BP Statistical Review of World Energy June 2017. https://www.bp.com/content/dam/bp/en/corporate/pdf/energy-e conomics/statistical-review-2017/bp-statistical-review-of-world -energy-2017-full-report.pdf (letöltve: 2018. április 17.).

24. Mika, L. T., Cséfalvay, E., Németh Á. Chem Rev. 2018, 118, 505-613., https://doi.org/10.1021/acs.chemrev.7b00395

25. Cséfalvay, E., Akien, G.R., Qi, L., Horváth, I.T., Catalysis Today, 2015, 239, 50-55., https://doi:10.1016/j.cattod.2014.02.006

26. Horváth, I.T., Cséfalvay, E., Mika, L.T., Debreczeni, M., ACS Sustainable Chem. Eng., 2017, 5, 2734-2740., https://doi.org/10.1021/acssuschemeng.6b03074

27. Cole-Hamilton, D.J., Science 2003, 299, 1702-1706., https://doi.org/10.1126/science.1081881

28. Collis, A.E.C., Horváth, I.T., Catal. Sci. Technol. 2011, 1, 912-918., https://doi.org/10.1039/c1cy00174d

29. Sheldon R.A., Woodley, J.M., Chem. Rev., 2018, 118, 801-838., https://doi.org/10.1021/acs.chemrev.7b00203

30. Hoekstra, M.S., Sobieray, D.M., Schwindt, M.A., Mulhern, T.A., Grote, T.M., Huckabee, B.K., Hendrickson,V.S. Franklin, L.C., Granger E.J., Karrick, G.L., Org. Process Res. Dev., 1997, 1, 26-38., https://doi.org/10.1021/op9600320

31. Martinez, C.A., Hu, S., Dumond, Y., Tao, J., Kelleher, P., Tully, L., Org. Process Res. Dev., 2008, 12, 392-398., https://doi.org/10.1021/op7002248

32. De Rege, P.J.F., Gladysz, J.A., Horváth, I.T., Science, 1997, 276, 776-779., https://doi.org/10.1126/science.276.5313.776 


\section{Conservative evolution in green chemistry}

Chemists synthesized to date more than hundred million new compounds, most of which are alien to nature, thus the source of enormous pollution. As time passed, chemists became aware of potential risks and dangers. Green chemistry began as a list of necessary measures, to be followed in the laboratory, in order to avoid emission of harmful chemicals. In this paper we present foundations of green chemistry on the basis of two basic principles. Conservative evolution refers to the observation that throughout the history of the universe old constructs such as elementary particles, amino acids, or living cells remained conserved while the world evolved in its complexity. Industrial metabolism refers to the application of processes in industry, which are similar to biological metabolism. Concepts of green chemistry are discussed in the light of these principles, providing examples from recent chemical practice. First we treat atom economy. The manifestation of industrial metabolism can be exemplified by the second principle of Green Chemistry. i.e., synthetic methods should be designed to maximize the incorporation of all atoms used in the reaction into the final product, which allows minimization or even elimination of useless or harmful wastes. Atom economy is a metric of chemical transformations and it is able to classify a reaction as green. In most cases chemistry needs auxiliary substances to establish the conditions of a perfect atom economic reaction. As a result, the environmental aspects should be evaluated by the fate of these substances after isolation of the product. Safer chemicals are needed, therefore chemical products should be designed to affect their desired function while minimizing their toxicity. According to the fourth principle of green chemistry, chemicals should be designed to provide their desired function and minimizing their toxicity. One of the excellent examples of such chemicals is $\gamma$-valerolactone which was proposed as a sustainable liquid for the production carbon-based chemicals. Furthermore, the use of safer solvents should be emphasized. Solvents are essential parts of a number of chemical reactions and solvent friendly processes have been developed in several laboratories. These have many advantages in various operations including the simple regulation of temperature, moderation of exothermic reactions, dissolution of solids and facilitation of mixing. Millions of reactions can only operate in liquid media. As an outcome, the industrial activities involving solvents result in the release of volatile organic compounds including conventional solvents into the environment. Conventional organic solvents should be avoided their amount used in a reaction should be minimized. First of all, water, furthermore ionic liquids, glycerol, fluorous solvents, organic carbonates and supercritical carbon dioxide belong to the safe solvent category. Ionic liquids attracted considerable attention as alternative reaction media for a large variety of chemical transformations, due to their extremely low vapor pressure, good solvating properties, reasonable thermal stability, and other properties. While a huge variety of ionic liquids are utilized in a small laboratory scale, their large scale application is relatively rare. Bioliquids involving biomass-based waste represent a novel replacement of conventional organic solvents in well-established chemical transformations. Although some of them such as ethanol are well-known reaction media, the characterization of new candidates, like $\gamma$-valerolactone and possible applications have come into focus and are subject of recent researches. A further alternative is the replacement of fossil-based resources by renewable substitutes. Considering the exploding population of the Earth, the selection and consumption of appropriate resources have become a controversial issue due to the dramatically increased utilization of available resources. Thus, the production of energy and carbon based chemicals from biomass cannot compete either directly or indirectly with food or feed production. On the other hand, this issue involves the increasing demand of land use. Although biomass could be an ideal alternative, its sustainable utilization primarily depends on whether we can have enough resources to cover increasing needs of fuels and chemicals. A solution to the biomass problem could be the use of lignocellulose-rich wastes. A new definition of sustainability using fundamental evolutionary principles and natural mechanisms can be given. Thus, resources including energy should be used at a rate at which they can be replaced naturally and the generation of waste cannot be faster than the rate of their remediation. According to the ninth amendment of green chemistry, catalytic reagents should be used, the amount of which will not be reduced during various reactions. Catalysis is a further means for the reduction of harmful wastes. The transition metal-assisted homogeneous catalysis offers an efficient tool for the transformation of a variety of organic substrates over their heterogeneous counterparts. It has to be emphasized that they have significantly higher selectivity and work under milder operating conditions. The catalyst separation and even recycling have been a great challenge and subject of recent research area. To overcome the separation difficulties of homogeneous catalysts, several attractive solutions have been developed. Biocatalysis offers a solution for the industrial production of biologically active compounds with one or more chiral centers. This was recognized by pharmaceutical companies that have integrated green and sustainable methodology with traditional medicinal chemistry. At last, in situ analysis, one of the fundamental processes of life, can be utilized. In our body deoxyribonucleic acid is continuously attacked and damaged by external influence such as UV radiation and carcinogenic chemicals including free radicals. During cell division, it is replicated, however, the cell recognizes and corrects errors that occurred. In situ analysis can be introduced to make chemical processes clean. The application of in situ spectroscopy plays a key role in discovering the mechanism of reactions involving the characterization of intermediates in real time. Chemistry contributed a lot to technological evolution by inventing hundreds of millions of chemical reactions leading to new materials, which never existed before in the history of the Universe. New substances, if interacting with living systems in sufficient quantity, may be harmful or even poisonous, this is one of the reasons why chemistry has a wrong image in the public. Green chemistry strives to reduce, or even eliminate, the danger due to the appearance of novel materials in nature by following certain rules. These correspond to the principle of conservative evolution, namely that only those new constructs, emerging along the long history of the Universe, may survive, which are well anchored on already existing ones. Successful constructs survive even for billions of years, while materials or processes, which do not fit into natural order, disappear within a limited time. 